\title{
Exploring the Impact of Coronavirus Pandemic on World Prisons: An Overview of Global Responses and Future Implications
}

\author{
Madhumita Pandey \\ Lecturer in Criminology, Helena Kennedy Centre for International Justice, \\ Sheffield Hallam University, Sheffield, United Kingdom \\ E-mail:m.pandey@shu.ac.uk
}

\begin{abstract}
While governments and international organizations6. continue their fight against the 2019 Corona virus disease, it is important to not overlook those in prisons and detention centres around the world, currently deprived of their liberty and rights, as they are likely to be more vulnerable to this outbreak than the general population. Given the nature of confinement, prisoners live in close proximity with each other for prolonged periods of time which often acts as a source for amplifying and spreading infectious diseases. With this in mind, the aim of this article is to present an overview of the impact of Corona virus pandemic on world prisons and the subsequent global responses to combat this unprecedented crisis. The article concludes with implications for mental health of prisoners and deliberates on decarceration as a way forward.
\end{abstract}

Keywords: Prisons, Health Risk Management, Prisoners, Pandemic, Preparedness, Human Rights

\section{INTRODUCTION}

An outbreak of coronavirus diseases or COVID-19 began in Wuhan, Hubei province, China in December 2019. Wuhan became the heart of this epidemic, raising alarms and causing immense concern not only within China but internationally. Within weeks cases started appearing outside China as the virus rapidly spread throughout the world. Figure 1 below presents the timeline of early stages of COVID-19 outbreak [1]. According to the World Health Organization (WHO) Situation Report - 72, on 1 April 2020 (which is when the scholarship of this paper began), there were 823,626 confirmed COVID-19 cases and 40,598 related deaths globally (and these are likely to rise) [2]. The WHO defines coronavirus disease as "an infectious disease caused by a newly discovered coronavirus" [3]. On their website, the WHO outlines the following to prevent infection and to slow transmission of COVID-19:

1. Wash your hands regularly with soap and water, or clean them with alcohol-based hand rub.

2. Maintain at least 1 metre distance between you and people coughing or sneezing.

3. Avoid touching your face.

4. Cover your mouth and nose when coughing or sneezing.

5. Stay home if you feel unwell.
Refrain from smoking and other activities that weaken the lungs. Practice physical distancing by avoiding unnecessary travel and staying away from large groups of people [3].

Many scientists, medical experts, politicians and world leaders have since promoted social distancing and demanded citizens across the world to self-isolate in case they exhibit any of the COVID-19 related symptoms. India's Ministry of Health and Family Welfare [4] advises people to "self-isolate by staying at home if you begin to feel unwell, even with mild symptoms such as headache, low grade fever (37.3 $\mathrm{C}$ or above) and slight runny nose, until you recover". Similarly, in the United Kingdom, the National Health Service [5] recommends people to not leave the house and self-isolate if they have either "a high temperature - this means you feel hot to touch on your chest or back (you do not need to measure your temperature) or a new, continuous cough - this means coughing a lot for more than an hour, or 3 or more coughing episodes in 24 hours (if you usually have a cough, it may be worse than usual)". Irrespective of the geographical region, the primary goal of all public health measures over this year has been to prevent person-to-person spread of coronavirus disease by distancing people in order to disrupt transmission.

Wilder-Smith and Freedman [6] believe that the greatest tools we have at hand are isolation, quarantine, social distancing and community containment. They define 'isolation' as "the separation of ill persons with contagious diseases from non-infected persons to protect non-infected persons, and usually occurs in hospital settings".Another effective tool, which is also one of the oldest 'quarantine',helps in controlling communicable disease outbreaks [7]. This public health practice can be traced back to $14^{\text {th }}$ century Italy, where plague-infected ships arriving at the Venice port had to wait for 40 days (in Italian: quarantagiorni) to disembark [8]. 'Social distancing' is another measurethat works to reduce interactions between people in the broader community. This is done to ensure that unidentified individuals carrying the infection can be isolated in order to reduce chances of transmission [9]. This is particularly crucial for managing COVID-19 as the disease is transmitted by respiratory droplets and airborne precautions must be taken. 


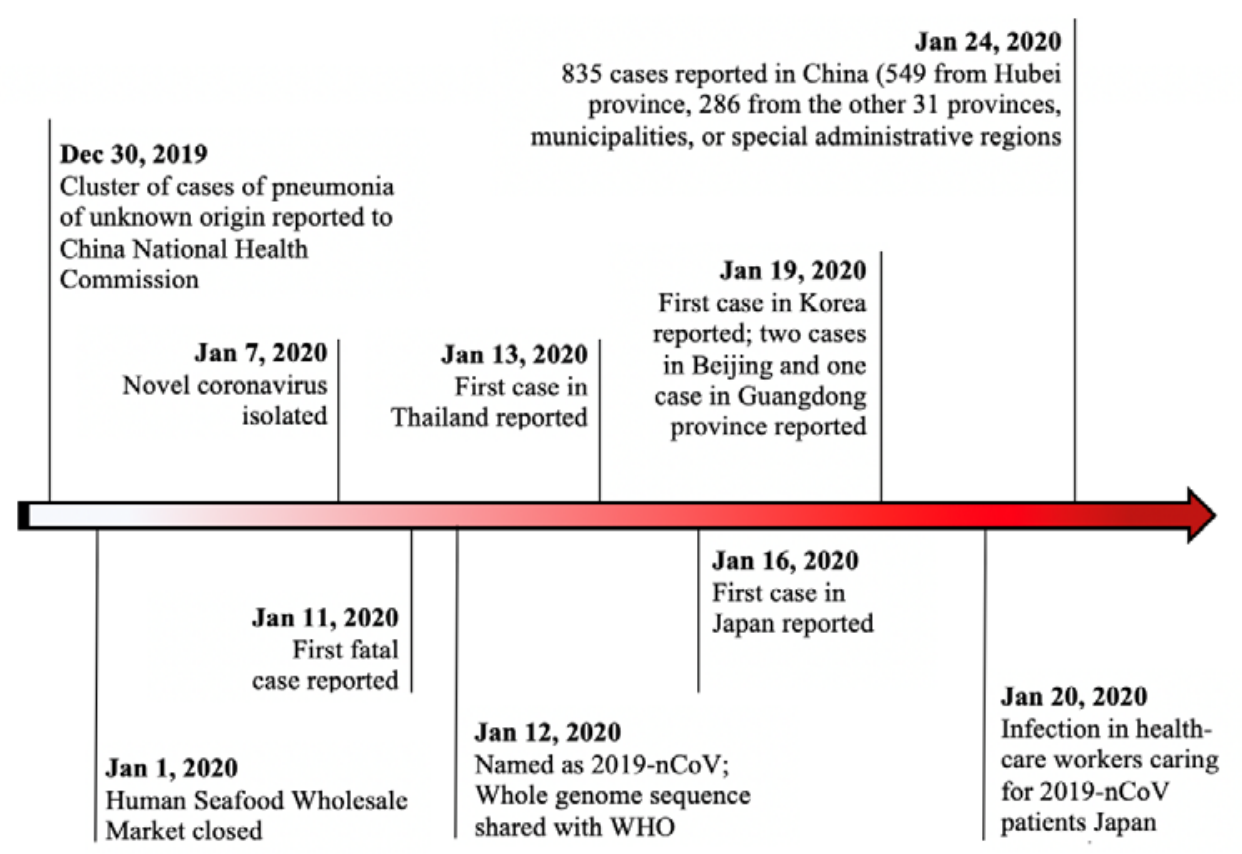

Fig.1 Timeline of early stages of COVID-19 outbreak

On 26 March 2020, the BBC reported that Edwin Hillier, an inmate at Her Majesty's Prison (HMP) Littlehey, Cambridgeshire (a category $\mathrm{C}$ male sex offenders' prison) had died of COVID-19, making him the first British prisoner to die after contracting the disease [10]. The same article then went on to report how a second prisoner in HMP Manchester had also died after contracting coronavirus. According to the World Prison Brief, there are more than 11 million people that are held in penal institutions throughout the world [11]. It was noted that:

"Overcrowding is an obvious cause of and contributing factor in many of the health issues in prisons, most notably infectious diseases and mental health issues. The latest data shows that 22 national prison systems hold more than double their capacity, with a further 27 countries operating at $150-200 \%$."

Overcrowded prisons can pose many challenges, particularly in the area of health and sanitation, and can lead to violent conditions that are damaging to the physical and mental wellbeing of prisoners [12][13][14]. This concern is also echoed by Fazel and Baillargeon [15] who argue that prison populations are at a much higher risk of infectious diseases than the outside communities. Furthermore, researchers note that, "People entering jails are among the most vulnerable in our society, and during incarceration, that vulnerability is exacerbated by restricted movement, confined spaces, and limited medical care" [16]. This is also a core feature of the United Nations' Nelson Mandela Rules [17], in particular Rule 24 which states that,

The provision of health care for prisoners is a State's responsibility. Prisoners should enjoy the same access to necessary health-care services free of charge without discrimination on the grounds of their legal status. Healthcare services should be organized in close relationship to general public health administration and in a way that ensures continuity of treatment and care, including for HIV, tuberculosis and other infectious diseases, as well as for drug dependence.

While prisons are commonly known as "closed environments", researchhas highlighted how the prison boundaries are actually semi-permeable as both prison staff and inmates move between the prison and the community [18]. They also argue that this aspect of the prison not only makes it easy for communicable diseases to circulate within the confined spaces but also makes its way into the community. As I progress writing this article, the figures each day are on the rise. Figure 2 below presents the number of confirmed coronavirus cases for selected countries as of 13 April 2020 [19].

It is worth noting that the number of confirmed cases is lower than the number of total cases as there is currently limited testing in most countries. Therefore, given the WHO guidelines of social distancing, I wonder, how are prisons managing the impact of coronavirus disease on prisoner populations around the world?

Prisons have inadequate space for social distancing, the regulated access to soap and water acts as a barrier for frequent hand washing and hand sanitizers are generally banned due to their high alcohol content [20]. With this in mind, the aim of this article is to present a brief overview of the impact of coronavirus pandemic on world prisons and the subsequent global responses. 


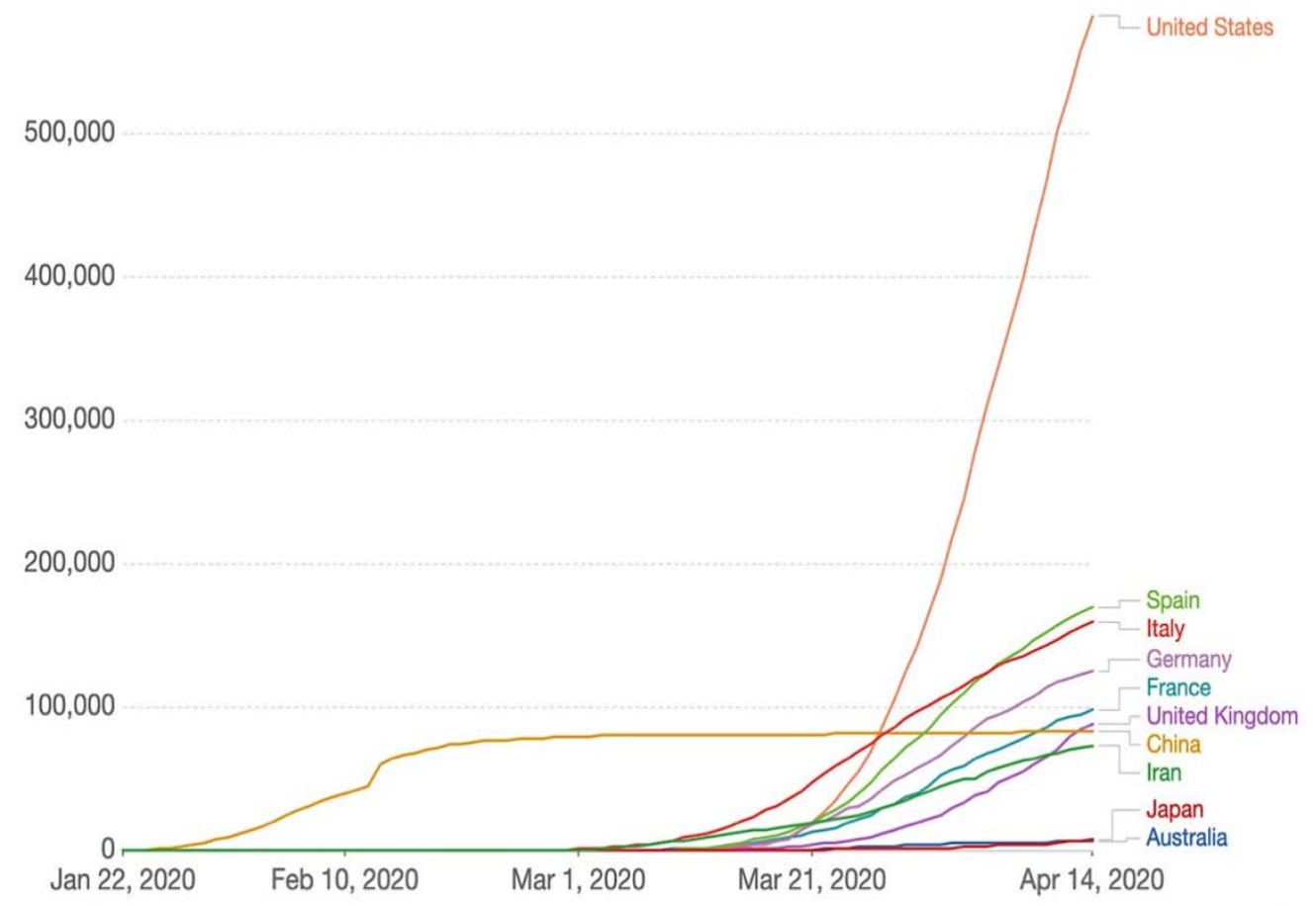

Fig. 2 Number of confirmed Coronavirus cases for selected countries

\section{COVID-19 IN PRISONS: OVERVIEW OF GLOBAL RESPONSES}

As the coronavirus disease began striking prisons, jails, detention centres around the world, the UN High Commissioner for Human Rights, Michelle Bachelet [21] urged governments to, "not forget those behind bars". In the United Kingdom, the government's response to managing COVID-19 in prisons was first published on 13 March 2020 through the Ministry of Justice and Her Majesty's Prison and Probation Service, which claimed that around 88 prisoners and 15 staff have tested positive for coronavirus.Prisons have been working closely with the public health services and NHS to ensure the safety of prisoners and staff. According to the website, "Handwashing facilities are available to prisoners, staff and visitors and we have worked closely with suppliers to ensure the supply of soap and cleaning materials" [22]. Furthermore, after a robust risk assessment, prisoners who are within two months of their prison release will be 'temporarily released from prison' as part of the national effort to protect the NHS. Lord Chancellor and Justice Secretary Robert Buckland QC MP said:

"This Government is committed to ensuring that justice is served to those who break the law. But this is an unprecedented situation because if Coronavirus takes hold in our prisons, the NHS could be overwhelmed and more lives put at risk. All prisoners will face a tough risk assessment and must comply with strict conditions, including an electronic tag, while they are closely monitored. Those that do not will be recalled to prison."
In light of the emerging coronavirus cases in prions, Reform - a leading Westminster think tank for public service reform, published theirreport on the challenge to manage the prison population in the context of COVID-19 threat. The report assessed various measures that can be implemented to manage this unprecedented crisis, such as extending home detention curfew (HDC), transfer of short sentence prisoners to HDC and banning sentences of six months or less [23].

More recently, the British Society of Criminology's Prison Research Network (BSCPRN) wrote an open letter to the UK government on the response to COVID-19 in prisons. This letter was inspired by the open letter which was coordinated by the Prof Lorana Bartels from Australian National University and Prof Thalia Anthony from the University of Technology Sydney and was signed by more than 400 legal experts to call on Australian governments to release prisoners who are most vulnerable to a COVID-19 outbreak [24]. The letter also highlights how the risks of coronavirus disease are greater for Indigenous inmates, which account for one in four of the adult prisoner population in Australia, as they have higher rates of underlying chronic diseases. In response to the COVID-19 pandemic, New South Wales became the first government in Australia to initiate legislation permitting certain inmates to be released to control the spread of corona virus in prisons. In her opinion piece for The Guardian, ProfAnthony (one of the two authors of the open letter) explained that this step in the right direction can take the load off the overcrowded 14,000-plus prisoner population of New South Wales [25]. The BSCPRN open letter also urgesthe government to take immediate action to reduce 
the risk of transmission of COVID-19 in the UK's criminal justice systems, especially prisons, youth offender institutes and immigration detention centres. As members of this network, we all felt that much more can be done to manage this crisis and provide adequate health care services to all those in prisons, especially the more vulnerable groups. However, there have been questions over the "real" numbers of prisoners being released in the UK. The Centre for Crime and Justice Studies expressed concerns over the decline in prison population in England and Wales as compared to the rest of Europe since the start of COVID-19 outbreak [26]. Compared to England and Wales' mere two percent drop, the French prison population has fallen by fourteen percent, closely followed by the Italian prison population which fell by ten percent. On the hand Portugal has released seventeen percent of its prison population under the early release schemes. The centre's latest infographics illustrated prison population changes across Europe in response to COVID-19. These have been presented in Figure 3 below.
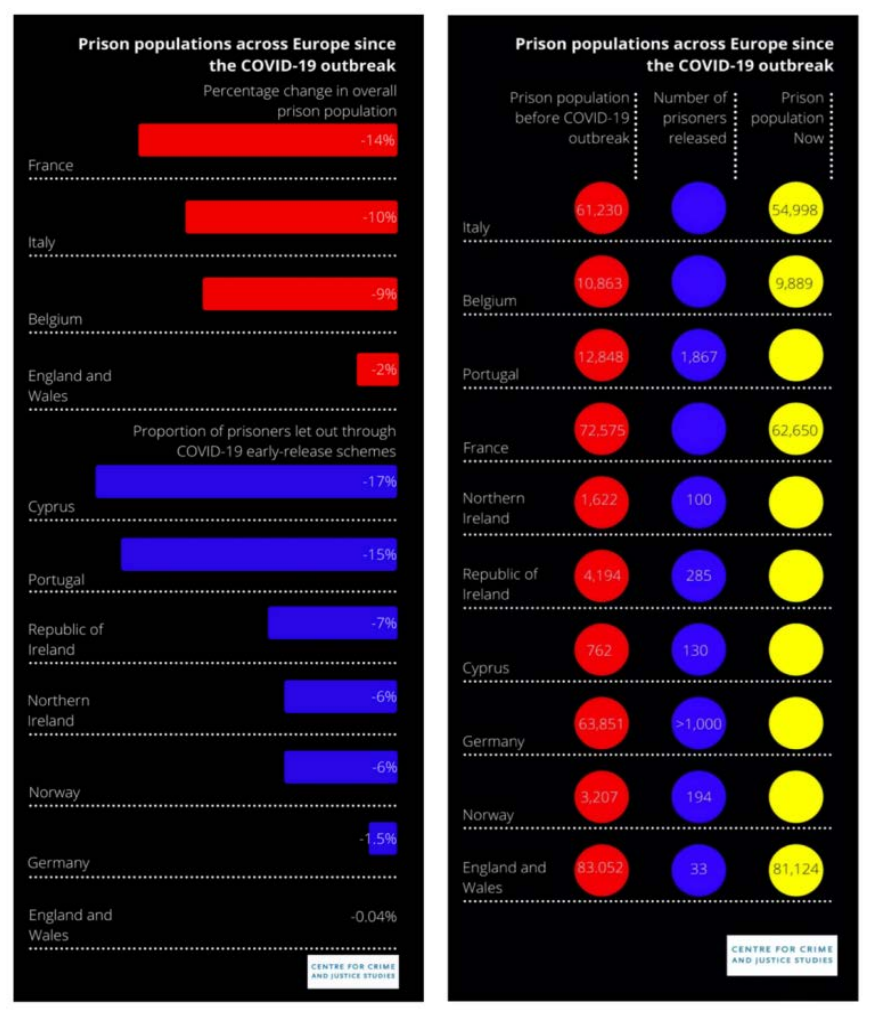

Source: Centre for Crime and Justice Studies

Fig. 3 Changes in prison population changes across Europe in response to COVID-19

It was also noted that several European countries did not particularly set measures for prison management in light of the COVID-19 crisis. The approaches of Netherland came under fire as nothing more than ban on prison visitors and on prisoner being granted day release was announced [27]. Similarly, Belgium implemented one visitor per prisoner rule[95]. In his recent interview, Professor Marcelo Aebi (University of Lausanne), who has co-authored the latest
Council of Europe Annual Penal Statistics, describes the situation of the 1.5 million prisoners in prisons in Europe. "I think that European prisons are facing their major challenge since World War Two because here, you have two factors. One is overcrowding and the other one which you mentioned is the age of the prison population. The general age of the population in Europe is increasing and this is reflected also in the prison population. You have 15percent of persons aged more than 50 and roughly 2.4 aged more than 65 . So, if you combine overcrowding plus a considerable number of persons aged more than 50 and more than 65 , this is a terrible cocktail that can explode at any moment." [28]

Meanwhile, across the Atlantic, as of 22 April 2020, there were 776,093 total confirmed cases of coronavirus which had led to 41,758 deaths in the United Statesmaking it one of the worst affected countries in the world [29]. The U.S. has the world's biggest prison population, which is nearly 2.3 million people [30]. There have been many reports of inmates and prison workers contracting COVID-19 in the U.S. For instance, the Chicago Cook County Sheriff's Office [31] reported that as 21 April 2020, 235 detainees in custody at Cook County Jail were positive for COVID-19. This included 19 who were being treated at local hospitals. Furthermore, 192 detainees in custody were no longer positive and were being monitored at a recovery facility of the jail. Six detainees who tested positive for COVID-19 have died while receiving treatment at local hospitals. On 5 April 2020, Michael Tyson became the first person on Rikers Island in New York City to die from COVID-19. Since then, almost 362 people out of 3,974 have tested positive and six prison staff has died.The Economist [32] noted how this is six times higher than the infection rate in New York City as a whole. States across the U.S have responded differently to the crisis. While California and Kentucky released less than 4 percent of their prisoners, the state of Arizona decided to release none, not even those convicted of non-violent crimes [33]. At least five prisoners have died in Oakdale, a low-security federal prison in southwest Louisiana [34]. It is also useful to remind ourselves that these numbers, coronavirus reported positive cases and related deaths in prisons, are possibly undercounts. Similar issues are being raised in Canada. The Public Health Agency of Canada (PHAC) is the official authority for COVID-19, which is also overseeing the health and safety of prison employees and offenders. As of 14 March, 2020, the Correctional Service of Canada (CSC) suspended visits from public and volunteers, all temporary absences from instructions (unless medically necessary) and work releases for offenders [35]. Figures from CSC highlighted how in some of the worst hit institutions, every two out of three prisoners tested had contracted the virus. For instance, in Mission, British Columbia, 70\% of those tested have now contracted COVID-19 (60 out of 85), raising severe health concerns in the federal prison system.However, Reuters reported that efforts have been made to release prisoners allacross North America[36]. Canada released 1,000 inmates in Ontario and New Jersey 
in U.S. temporarily released nearly 1,000 low risk inmates and the New Jersey Supreme Court ordered the release of anyone in jail on a probation violation or for a minor offense in an effort to combat the rising risks of coronavirus. Furthermore, Texas suspended arrests for minor offenses; Oakland, California has released 314 lowlevel offenders [37].

If the Western world is struggling to manage this health crisis then it is perhaps reasonable to assume that the situation in Latin America looks grim. Human Rights Watch (HRW) [38] reported that like most countries around the world, Brazil also struggles with over-crowding in the penal system and this issue has only escalated since then. Almost four out of ten prisons in Brazil have no doctor or nurse on site. On 22 March 2020, it was reported that about 23 prisoners got killed and 83 were injured when a prison riot broke out in La Modelo Prison in Bogota [39]. The riot erupted over fears of corona virus spreading within prison walls. According to the preliminary observations of InterAmerican Commission of Human Rights, there were major human rights violations inside El Salvador's prisons with no proper basic infrastructure and hygiene[40]. The Washington Post also reported that in Izalco I prison, there were almost 94 men in a cell that is built to hold 28 inmates who took turns to sleep in the hammocks [41]. José Miguel Vivanco, Americas Director at Human Rights Watch said, "An outbreak of coronavirus in Latin America's prisons would be an enormous public health problem that would affect not just the detainees but also the rest of the population" [41].

Countries in the middle east started releasing prisoners as early as 3 March 2020 with Iranian government announcing that 54,000 prisoners (who had tested negative) had been temporarily released [42]. However, things weren't as smooth as they seemed. In March, nearly seven inmates had died due to COVID-19 in Urmia Central Prison while the prison authorities continued to downplay the spread of the epidemic [43]. The Prisoner Insider reported an escape attempt at Parsilon prison, where 250 prisoners tried to escape and law enforcement officers open-fired killing several prisoners [44]. Various checkpoints were created and martial law was announced to manage the situation. Numerous protests and riots were also reported from Lebanon. In the overcrowded prisons of Rumaniah and Zahle, prisoners rioted for their temporary release as they feared the spread of Covid-19 within the prison complex [45]. Only a few weeks later, prisoners set their beds on fire in Qubbah prison. Their families also gathered at the entrance of the prison in Tripoli and attacked the Lebanese army with stones injuring 13 soldiers [46]. Lynn Maalouf, Amnesty International's Middle East Research Director said, "Lebanon's prisons are full of people who simply should not be there, including hundreds of individuals who remain behind bars because the judiciary isn't processing their case in a timely manner or because they are unable to pay their fines or secure release warrants" [47]. Palestinian prisoners across Israeli prisons planned to start a hunger strike in order to protest against the administration's lack of preparedness for the Coronavirus epidemic. They condemned the administration's decision to remove more than 140 health products (including soap and shampoo) which used to be available earlier [48]. It was also reported that overseven hundred prisoners are in need for medical care, seventeen of which are said to be in critical condition in the prison hospital [49].

Overcrowding of prisons is quite the norm in developing countries, particularly in the region of South Asia. According the World Prison Brief, prisons in India, Bangladesh and Pakistan are operating at $117 \%, 201 \%$ and $171 \%$ of its capacity respectively [50]. Efforts were made at both national and local levels in India in response to managing COVID-19 in prisons. The Director General (Prison) of Uttar Pradesh, explained how a special task force had been set up to monitor the situation across all 71 operating jails in the state [51]. He also added, "Masks are also being stitched in-house by the prisoners in 21 jails of the state and 15,000 masks have been distributed to the inmates and prison staff. Requests have been made to the courts to conduct remand proceedings through video conferencing. In case it is not feasible, request for deferment have been made to the district judges". In Delhi's Tihar Jail, which is Asia's largest prison complex, isolation wards were prepared for inmates with COVID-19 symptoms and only after medical screening, new inmates were being made to stay in separate barracks [52]. Furthermore, Tihar authorities urged the government to release 1,500 prisoners on parole or furlough and roughly around the same number of under-trial prisoners to be released on interim bail. In Bangladesh, according to the home ministry's special coordination cell, similar precautions were taken where isolation centreswere set up across six jails [53]. In Pakistan, Islamabad High Court released 408 prisoners on a temporary basis [54]. To tackle the COVID-19 situation in Sri Lankan prisons, UNODC and the European Union (EU) stepped in to support by distributing personal protective equipment (PPE) and sanitization items, along with ten computers to keep court hearings ongoing remotely [55].

In Northeast Asia, China and South Korea sparked concerns not only for the rise in COVID-19 cases in the general population but also within prisons. According to the China Central Government Report on COVID-19, by the end of February, there were more than 500 new COVID-19 cases across five prisons (excluding Hubei province) [56]. Concern was also expressed over the spread of infection within Chinese prisons as, "the tuberculosis infection rate in prisons of about 1250 cases per 100000 is 3.4 times China's national average" [57]. South Korea emerged successful in keeping COVID-19 at bay without implementing a total lockdown setting an example for the rest of the world. As soon as new confirmed cases of COVID-19 rose in Daegu and North Gyeongbuk Province of South Korea, several medical workers within the correctional facilities had to quarantine [58]. This void of prison healthcare was filled by 
public health doctors, who were urgently dispatched to affected correctional facilities.

Overall, prisons and detention centres around the world are battling the spread of COVID-19 and have also responded in accordance with local governments as well as the guidelines of international organizations. However, we are yet to see the full picture of the devastating effects COVID19 will have on world's prisons and detention centres, particularly with regard to implications for mental health in confinement.

\section{MENTAL HEALTH IMPLICATIONS IN CONFINEMENT DURING COVID-19}

In light of the COVID-19 global pandemic, another key issue that has resurfaced is mental health of prisoners. Studies over the years, most of which focus on high-income countries, have shown that prison populations have a significantly higher incidence of mental disorders when compared to the general population [15]. Most countries have a higher numbers of drug addicts along withthose who suffer from diagnosable mental disorders [59]. Furthermore, the global number of older prisoners has also been increasing over the past decades, which also reflects the growing old population outside prisons [60][61][62][63][64]. More than two decades ago, Beitchman's research highlighted that an increasing number of prisoners over the age of 50 were being diagnosed with a major mental health disorder [65]. Likewise, researchers havefound that older prisoners with mental health issues are not only the most rapidly growing cohort within the prison population but also one that is enduring worse-off health [60][66]. This was also observed in the work of Moschetti et al., [67] and Nowotny et al., [61], where it was found that older prisoners have higher somatic and mental disorders as comparedto the younger prison population. Haesen et al.'s systematic review found that older prisoners not only have higher incidence of mental health disorders compared to the younger prisoners but the likelihood of their alcohol use is also high [68]. More recently, Fovet et al., [69] highlighted the challenges being faced by the mental health workers in French correctional facilities with regard to situations involving prisoners' forced drug and substance withdrawal, anxiety caused due to concerns for their wellbeing and their family's safety and decompensation or decline in those with severe psychiatric ailments. It was also found that early release from prisons was also a cause of concern and those recently released were found to be at a high risk of selfharm and drug overdose. Overall, their study also stressed on the need to minimize the notorious effects of "revolving prison doors", that is to effectively manage the communication between prison health services with those outside to avoid any serious health consequences for prisoners. Therefore, there is a strong need to ensure access to treatment and wellbeing, particularly in the current COVID-19 climate.
Ethical dilemmas and debates around prison preparedness for pandemics such as influenza, tuberculosis. and AIDS along with other chronic diseases, particularly in the context of continued care of prisoners who have to share limited resources, have long dominated prison health management literature [70][71][72][73][74][75][76]. In the present crisis, there have been many strategies to segregate COVID-19 positive cases from other people in prison, however such a step can lead to further stressors based on the nature of isolation. Isolation practices quite closely resemble or maybe perceived as solitary confinement, which can result in damanging psychological consequences especially for those individuals who have an underlying mental illness. Isolation can be complex in correctional facilities and continues to be a major challenge.

In most prisons, the only areas that can be utilized for quarantine will be segregation cells that are used to house individuals in solitary confinement [77]. Wildeman and Andersen's research explored the relationship between being placed in solitary confinement and mortality in previously incarcerated Danish individuals. They found a relationship between solitary confinement and elevated mortality due to non-natural cause. The researchers suggest a need for interventions for the vulnerable population that gets placed in solitary confinement [78]. Recently, in their letter to the Editor of Australian and New Zealand Journal of Psychiatry, Stewart, Cossar and Stoové argue that, "the absence of meaningful social contact, environmental stimuli and engagement in purposeful activities through solitary confinement increases the likelihood of severe psychological distress and adverse outcomes post-release" [79]. Even before COVID-19, incarceration had been identified as a factor contributing towards mortality particularly among those with mental and behavioural health disorders [80][81].

We already know that it is imperative to preserve hopefulness and social relations/connections during incarceration [82]. Therefore, access to the outdoors and recreational activities, mental health counsellors or centres and some form of contactless socialization must be integrated into COVID-19 quarantining practices within custodial settings and made universally available to the individuals who are incarcerated. Wurcel et al., urge prison governing bodies to apply "Tele-health" wherever possible [83]. In some places, the response to restricted visitation due to COVID-19 has been quite extreme, such as the riots and fatalities in Italian, Lebanese and South American prisons (to name a few), which means a greater focus on psychological well-being is needed during and post this pandemic.

\section{IS DECARCERATION THE NEW WAY FORWARD?}

Corona virus disease is having a drastic effect on not only social control but also the criminal justice systems of the world. We are seeing broadened executive decision-making 
with regards to the laws, radical changes to sentencing parameters as well as expansion of scope for crimes and penalties. On 25 March 2020, the UN Subcommittee on the Prevention of Torture and Other Cruel, Inhuman or Degrading Treatment or Punishment (SPT), urgedgovernments to reduce prison and other detention populations wherever possible in response to corona virus [84]. Perhaps, I am over estimating but as we find ourselves at this historical juncture, where prisoners across the world are being released in large numbers, it is worth reflecting on opportunities for future solutions based on the principles of decarceration. Note that "decarceration" as a word is yet to be found outside legal dictionaries, however it is a central process within community care and community control that has enormous implications for society. Trends show how mass incarceration affects vulnerable sections of the population, as people of colour, those in poverty and with behavioural and health disorders are overrepresented in prisons [85]. Furthermore, mass incarceration has also proven to be financially unsustainable [86].

Growing evidence indicates that we will be moving to an era of decarceration [87][88][89]. A recent study conducted by Data For Progress, a US based not profit think tank, also found strong public support for an approach that significantly reduces jail and prison populations in order to reduce the spread of the coronavirus [90]. The study found that, "Sixty-six percent of likely voters, including 59\% of those who are 'very conservative', said that elected officials should be considering measures to reduce overcrowding in prisons and jails as a response to coronavirus"[90]. There is no better time than now to rethink human practices and envision solutions for the future keeping in mind the millions of people that are confined in what are effectively incubators for viral infections. As UCLA law professor Sharon Dolovich puts it in her commentary piece for The Appeal, "Every public official with the power to decarcerate must exercise that power now" [37].

Decarceration permits some confined individuals to move back to the community and get access to resources, which are commonly of higher quality than those in correctional facilities. In light of this present COVID-19 crisis, decarceration as an approach can lessen the number of individuals who remain imprisoned, which can make way for greater social distancing and improved access to health and well-being resources. Until now, there have been no new reported COVID-19 outbreaks in regions where decarceration has been implemented. Many previous conditions where speedy decarceration was applied can be used to support it as a sound public policy and well-being strategy. In 2011, the law in the state of California readjusted sentencing parameters for certain crimes from the state to the county. This led to the release of nearly 30,000 people in about a year, the largest ever seen in U.S history, without impact on violent crime [91]. Sundt et al.,'s research lends support to earlier studies that have used California's realignment law to study the relationship between incarceration and crime [92][93]. Similarly, back in
2001, Russia passed a law that led to the release of 101,000 juveniles, people held on bail, and people convicted of minor crimes in a year, without any negative impact on the country's national crime [94].

\section{CONCLUSION}

We can view this crisis as an opportunity. As the coronavirus epidemic threat rises, we are seeing something that was unimaginable months ago - over 300,000 people from prisons around the world have been released. Careful deliberation and thoughtful planning for COVID-19 mitigation in correctional facilities and detention centres is imperative. We need action now, starting with engagement of key stakeholders to identify the current and future needs of prisons, jails and detention centres to combat this pandemic and to be prepared for any future crisis of this nature. To conclude, in the words of the late Nelson Mandela [96], who spent 27 years of his life in prison,

"It is said that no one truly knows a nation until one has been inside its jails. A nation should not be judged by how it treats its highest citizens, but its lowest ones.

\section{NOTES}

For more up to date situation report, visit WHO https:/www.who.int/emergencies/diseases/novel-

coronavirus-2019/situation-reports.

For more up to date information on the COVID-19 impact on European prisons, see the European Prison Observatory http://www.prisonobservatory.org/index.php?option=com_c ontent\&view=article\&id=32: covid-19-what-is-happeningin-european-prisons\&catid $=7 \&$ Itemid $=101$

British Society of Criminology, Prison Research Network: Open Letter to the UK Government on the response to C19 in prisons https://docs.google.com/forms/d/e/1FAIpQLSepJD9zyBzh Q6kx9Z0J4ng-AqN1-ANz9HF8F9qg6f7BcgSzjQ/viewform.

\section{REFERENCES}

[1] Wang, C, Horby, PW, Hayden, FG., \& Gao, GF. (2020).A novel corona virus outbreak of global health concern. The Lancet, 395(10223), 470-473.

[2] World Health Organization. (2020). Situation Report - 72.Retrieved on 2 April 2020 from https://www.who.int/docs/defaultsource/ coronaviruse/situation-reports/20200401-sitrep-72-covid19.pdf?sfvr $\mathrm{sn}=3 \mathrm{dd} 8971 \mathrm{~b} \_$.

[3] World Health Organization. (2020). Coronavirus. Retrieved on 2 April 2020 from https://www.who.int/health-topics/coronavirus $\#$ tab $=$ tab 1

[4] Ministry of Health and Family Welfare, Government of India. (2020). COVID-19 India. Retrieved on 2 April 2020 from https://www.mohfw.gov.in/

[5] National Health Service. (2020). Symptoms and what do to Coronavirus (COVID-19). Retrieved on 2 April 2020 from https://www.nhs.uk/conditions/coronavirus-covid-19/symptoms-andwhat-to-do/

[6] Wilder-Smith, A., \& Freedman, DO. (2020). Isolation, quarantine, social distancing and community containment: pivotal role for oldstyle public health measures in the novel coronavirus (2019-nCoV) outbreak. Journal of Travel Medicine, 27(2).

[7] Cetron, M. \& Simone, P. (2004). Battling 21st-century scourges with a 14th-century toolbox. Emerging infectious diseases, 10(11), 2053. 
[8] Centre for Disease Control and Prevention. (2020). History of Quarantine. Retrieved on 2 April 2020 from https://www.cdc.gov/ quarantine/historyquarantine.html

[9] Lee, V. J., Chiew, C. J., \& Khong, W. X. (2020). Interrupting transmission of COVID-19: lessons from containment efforts in Singapore. Journal of Travel Medicine. (Accepted Manuscript) https://doi.org/10.1093/jtm/taaa039

[10] BBC. (2020). Coronavirus: First UK prison Covid-19 death confirme. Retrieved on 6 April 2020 from https://www.bbc.co. uk/news/uk-england-cambridgeshire-52047003

[11] Walmsley, R. (2018). World Prison Population Lists. World Prison Brief. Institute of Criminal Policy Research. Retrieved on 6 April 2020 from https://www.prisonstudies.org/

[12] UNODC. (2013). Handbook on Strategies to Reduce Overcrowding in Prisons. Available from:www.europarl.europa.eu/thinktank/en/ document.html?reference=IPOL_BRI\%282017\%29583113

[13] MacDonald, M. (2018). Overcrowding and its impact on prison conditions and health. International Journal of Prison Health. 14(2).

[14] Kinner, S. A., Young, J. T., Snow, K., Southalan, L., Lopez-Acuña, D., Ferreira-Borges, C., \& O'Moore, É. (2020). Prisons and custodial settings are part of a comprehensive response to COVID-19. The Lancet. Public Health.

[15] Fazel, S. \& Baillargeon, J. (2011). The health of prisoners. The Lancet 377(9769), pp 956-965. Available from: https://www.thelancet.com/journals/lancet/article/PIIS01406736(10)61053-7/fulltext

[16] Akiyama, M. J., Spaulding, A. C., \& Rich, J. D. (2020). Flattening the curve for incarcerated populations - Covid-19 in jails and prisons. New England Journal of Medicine. 382(22), 2075-2077.

[17] United Nations. (2015). The Standard Minimum Rules for the Treatment of Prisoners: Nelson Mandela Rules. Retrieved on 6 April 2020 from: https://www.un.org/en/events/mandeladay/mandela_ rules.shtml

[18] Snow, K. \&\& Levy, M. (2018). Harm Reduction in Prisons. In Kinner, S. \& Rich, D. (Eds). Drug Use in Prisoners: Epidemiology, Implications, and Policy Responses, 84.

[19] Roser, M., Ritchie, H. \& Ortiz-Ospina, E. (2020). Coronavirus Disease (COVID-19) - Statistics and Research. Available online at OurWorldInData.org. Retrieved on 14 April 2020 from: https://ourworldindata.org/coronavirus

[20] Stephenson, J. (2020). COVID-19 Pandemic Poses Challenge for Jails and Prisons. In JAMA Health Forum (Vol. 1, No. 4, pp. e200422-e200422). American Medical Association.

[21] UN News. (2020). UN rights chief urges quick action by governments to prevent devastating impact of COVID-19 in places of detention. Retrieved on 10 April 2020 from https://news.un.org/en/ story/2020/03/1060252

[22] Government of United Kingdom. (2020). Coronavirus (COVID-19) and prions. Retrieved on 6 April 2020 from https://www.gov.uk /guidance/coronavirus-covid-19-and-prisons

[23] Shilson-Thomas, A. (2020). Reducing the prison population: Extending Home Detention Curfew and scrapping short sentences. Reform. Retrieved on 12 April 2020 from https://reform.uk/research/ reducing-prison-population-extending-home-detention-curfew-andscrapping-short-sentences

[24] Australian Lawyers for Human Rights. (2020). Open letter to Australian governments on COVID-19 and the criminal justice system. Retrieved on 10 April 2020 from https://alhr.org.au/openletter-australian-governments-covid-19-criminal-justice-system/

[25] Anthony, T. (2020). Coronavirus is a ticking time bomb for the Australian prison system. The Guardian. Retrieved on 10 April 2020 from

https://www.theguardian.com/commentisfree/2020/mar/26/coronavir us-is-a-ticking-time-bomb-for-the-australian-prison-system

[26] Centre for Crime and Justice Studies. (2020). How do European states compare with England and Wales? Available from: https://www.crimeandjustice.org.uk/news/2020-05-01/covid-19-andeuropean-prison-population-changes

[27] The Guardian. (2020). 'Everyone will be contaminated': prisons face strict coronavirus controls. Available from https://www.theguardian. com/global-development $/ 2020 / \mathrm{mar} / 23 /$ everyone-will-becontaminated -prisons-face-strict-coronavirus-controls

[28] Council of Europe. (2020). Portal: Covid19. Available from https://www.coe.int/en/web/portal/covid-19-prisons
[29] Centre for Disease Control and Prevention. (2020). Cases of Coronavirus Disease (COVID-19) in the U.S. Retrieved on 22 April 2020 from https://www.cdc.gov/coronavirus/2019-ncov/casesupdates/cases-in-us.html

[30] Sawyer, W. \& Wagner, P. (2020). Mass Incarceration: The Whole Pie 2020. Prison Policy Initiative. Retrieved on 20 April 2020 from https://www.prisonpolicy.org/reports/pie2020.html

[31] Cook County Sheriff's Office. (2020). COVID-19 Cases at CCDOC. Retrieved on 22 April 2020 from https://www.cookcountysheriff.org/ covid-19-cases-at-ccdoc/

[32] The Economist. (2020). Prisons worldwide risk becoming incubators of covid-19. Available from https://www.economist.com/ international/2020/04/20/prisons-worldwide-risk-becomingincubators-of-covid-19

[33] Chapin, A. (2020). Governors are too cowardly to solve the coronavirus outbreak in prisons. Huffington Post. Retrieved on 12 April 2020 from https://www.huffingtonpost.co.uk/entry/governorscoronavirus-prisons_n_5e8f8ed9c5b6b371812dd9db?ri18n=true

[34] Gurman, S., Elinson, Z. \& Paul, D. (2020). Coronavirus puts a prison under siege. The Wall Street Journal. Available at https://www.wsj.com/articles/inside-oakdale-prison-our-sentenceshave-turned-into-death-sentences-11586191030

[35] Correctional Service Canada. (2020). COVID-19. Available at https://www.csc-scc.gc.ca/001/006/001006-1003-en.shtml

[36] Baker, L. (2020). Lock'em up or let'em out? Coronavirus prompts wave of prisoner releases. Reuters. Retrieved on 10 April 2020 from https://uk.reuters.com/article/us-health-coronavirus-prisonersreleased/lock-em-up-or-let-em-out-coronavirus-prompts-wave-ofprisoner-releases-idUKKBN21C38R

[37] Dolovich, S. (2020). Every public official with the power to decarcerate must exercise that power now. The Appeal. Available from https://theappeal.org/every-public-official-with-the-power-todecarcerate-must-exercise-that-power-now/

[38] Human Rights Watch. (1998). Behind bars in Brazil Available from https://www.hrw.org/legacy/reports98/brazil/Brazil-01.htm

[39] Al Jazeera. (2020). Columbia coronavirus: 23 killed in prison riot. Available from https://www.aljazeera.com/news/2020/03/colombiacoronavirus-23-killed-prison-riot-200323104057561.html

[40] Inter-American Commission of Human Rights. (2019). Priliminary Observations. Available from http://www.oas.org/en/iachr/media center/PReleases/2019/335.asp

[41] The Washington Post. (2020) 'Stripped of basic human dignity': Inside El Salvador's prisons. Available from https://www.washington post.com/graphics/2020/opinions/global-opinions/salvador-prisonphotos/

[42] BBC. (2020). Coronavirus: Iran temporarily frees 54,000 prisoners to combat spread. Retrieved from https://www.bbc.co.uk/news /world-middle-east-51723398

[43] Iran News Wire. (2020). 7 prisoners dead, 100 infected with COVID19 in NW Iran prison. Available from https://irannewswire.org/7prisoners-dead-100-infected-with-covid-19-in-nw-iran-prison/

[44] Prison Insider. (2020). Middle East: coronavirus, prison fever. Available from https://www.prison-insider.com/en/articles/moyenorient-coronavirus-la-fievre-des-prisons\#iran-5e820 cc96eac8

[45] Azhari, T. (2020). Riots rock overcrowded Lebanon prisons over coronavirus fears. Al Jazeera. Available from https://www.aljazeera. com/news/2020/03/riots-rock-overcrowded-lebanon-prisonscoronavirus-fears-200317164301234.html

[46] Geldi, M. (2020). Lebanon: Inmates set fires in amnesty bid amid pandemic. AA News. Available from https://www.aa.com.tr/en/lateston-coronavirus-outbreak/lebanon-inmates-set-fires-in-amnesty-bidamid-pandemic/1796521

[47] Amnesty International. (2020). Lebanon: Government must urgently release more prisoners to prevent spread of COVID-19. Retrieved on 24 April 2020 from https://www.amnesty.org/en/latest/news/ 2020/04/lebanon-government-must-urgently-release-more-prisonersto-prevent-spread-of-covid19/

[48] Hareetz. (2020). Palestinian Prisoners in Israeli Jails Threaten Hunger Strike Over Coronavirus Response. Availble from https://www.haaretz.com/israel-news/.premium-palestinian-prisonersin-israeli-jails-threaten-hunger-strike-over-coronavirus-1.8697309

[49] Middle East Monitor. (2020). Israel's jail conditions will kill Palestinian prisoners before coronavirus does. Available from https://www.middleeastmonitor.com/20200414-israels-jail- 
conditions-will-kill-palestinian-prisoners-before-coronavirusdoes/\#comment-4876974513

[50] World Prison Brief. (2020). Asia: India, Pakistan and Bangladesh. Available from https://www.prisonstudies.org/country/india

[51] Shukla, N. (2020). Coronavirus in India: UP prison department gears up to prevent infection in jails. India Today. Available from https://www.indiatoday.in/india/story/coronavirus-in-india-up-prisondepartment-gears-up-to-prevent-infection-in-jails-1657282-2020-0319

[52] Hindustan Times. (2020).Tihar Jail screens inmates for coronavirus, creates isolation ward. Available from https:/www.hindustantimes. com/india-news/tihar-jail-screens-inmates-for-coronavirus-createsisolation-ward/story-O2NEwz4LUH0ubCxgH2qroM.html

[53] Khan, J. M. (2020). 40 prisoners quarantined, 6 isolation units at jails. The Daily Star. Available from: https://www.thedailystar.net/city/ news/40-prisoners-quarantined-6-isolation-units-jails-1888378

[54] Geo News. (2020). Inmate at Lahore's Camp Jail tests positive for coronavirus. Available from https://www.geo.tv/latest/27 8937-pakistan-confirms-first-coronavirus-case-in-jail

[55] UNODC. (2020). UNODC and EU strengthen resilience of Sri Lankan prisons to COVID-19. Available from: https:/www.unodc.org/unodc/en/frontpage/2020/June/unodc-and-eustrengthen-resilience-of-sri-lankan-prisons-to-covid-19.html

[56] China Central Government. (2020). Report of covid-19 on 21 February 2020. Available from http://www.gov.cn/xinwen/ gwylflkjz25/wzsl.htm

[57] Yang, H., \& Thompson, J. R. (2020). Fighting covid-19 outbreaks in prisons. British Journal of Medicine. (369) 1362.

[58] Sae-im, J. (2020). Report from Daegu: Doctors guard prisons against COVID-19. Korean Biomedical Review. Available from http://www.koreabiomed.com/news/articleView.html?idxno=7750

[59] Gureje, O., \& Abdulmalik, J. (2019). Severe mental disorders among prisoners in low-income and middle-income countries: reaching the difficult to reach. The Lancet Global Health, 7(4), e392-e393.

[60] Pro, G., \& Marzell, M. (2017). Medical parole and aging prisoners: a qualitative study. Journal of Correctional Health Care, 23(2), 162172.

[61] Nowotny, K. M., Cepeda, A., James-Hawkins, L., \& Boardman, J. D. (2016). Growing old behind bars: Health profiles of the older male inmate population in the United States. Journal of aging and health, 28(6), 935-956.

[62] Fazel, S., Hayes, A. J., Bartellas, K., Clerici, M., \& Trestman, R. (2016). Mental health of prisoners: prevalence, adverse outcomes, and interventions. The Lancet Psychiatry, 3(9), 871-881.

[63] Cloyes, K., \& Burns, K. A. (2015). Aging prisoners and the provision of correctional mental health. Oxford Textbook of Correctional Psychiatry, 326.

[64] Aday, R. H., \& Krabill, J. J. (2012). Older and geriatric offenders: critical issues for the $21 \mathrm{st}$ century. Special needs offenders in correctional institutions, 1,203-233.

[65] Beitchman, B. Z. (1998). Project Golden gate: A Comprehensive Community Solution for mentally Ill, Older Ex-offenders.Dissertation Abstracts International: Section B: The Sciences and Engineering 58.

[66] Chodos, A., Ahalt, C., Cenzer, S., Goldenson, J., \& Williams, B. (2013). Characteristics of older adults who use the emergency room prior to jail detainment.: B76. Journal of the American Geriatrics Society, 61

[67] Moschetti, K., Stadelmann, P., Wangmo, T., Holly, A., Bodenmann, P., Wasserfallen, J. B., Elger, SB \& Gravier, B. (2015). Disease profiles of detainees in the Canton of Vaud in Switzerland: gender and age differences in substance abuse, mental health and chronic health conditions. BMC Public Health, 15(1), 872.

[68] Haesen, S., Merkt, H., Imber, A., Elger, B., \&Wangmo, T. (2019). Substance use and other mental health disorders among older prisoners. International journal of law and psychiatry, 62, 20-31.

[69] Fovet, T., Lancelevée, C., Eck, M., Scouflaire, T., Bécache, E., Dandelot, D., Giravalli, P., Guillard, A., Horrach, P., Lacambre, M., Lefebvre, T., Moncany, A. H., Touitou, D., David M., \& Thomas, P. (2020). Mental health care in French correctional facilities during the Covid-19 pandemic. L'encephale. 46(3), 60-65.

[70] Awofeso, N., \& Rawlinson, W. D. (2005). Influenza control in Australian prison settings: cost-benefit analysis of major strategies. International Journal of Prisoner Health, 1(1), 31-38.
[71] Ferguson, N. M., Cummings, D. A., Fraser, C., Cajka, J. C., Cooley, P. C., \& Burke, D. S. (2006). Strategies for mitigating an influenza pandemic. Nature, 442(7101), 448-452.

[72] Schwartz, R. D. (2006). Pandemic flu preparedness and response in corrections facilities. Infectious Diseases in Corrections Report, 9(10), 1-3.

[73] Van Niekerk, J. D. V. (2008). Lock up and stay: South Africa's sick prisons. South African Medical Journal, 95(5), 281.

[74] Maruschak, L. M., Sabol, W. J., Potter, R. H., Reid, L. C., \& Cramer, E. W. (2009). Pandemic influenza and jail facilities and populations. American Journal of Public Health, 99(S2), S339-S344.

[75] Spaulding, A. C., McCallum, V. A., Walker, D., Reeves, A., Drenzek, C., Lewis, S., \&Berkelman, R. L. (2009). How public health and prisons can partner for pandemic influenza preparedness: a report from Georgia. Journal of Correctional Health Care, 15(2), 118-128.

[76] Chikungwa, T., \&Mesatywa, N. J. (2013). The HIV/AIDS Pandemic in Prisons. Journal of Human Ecology, 44(3), 269-274.

[77] Williams, B., Ahalt, C., Cloud, D., Augustine, D., Rorvig, L., \& Sears, D. (2020). Correctional facilities in the shadow of COVID-19: unique challenges and proposed solutions. Health Affairs, 10.

[78] Wildeman, C., \& Andersen, L. H. (2020). Solitary confinement placement and post-release mortality risk among formerly incarcerated individuals: a population-based study. The Lancet Public Health, 5(2), e107-e113.

[79] Stewart, A., Cossar, R., \&Stoové, M. (2020). The response to COVID-19 in prisons must consider the broader mental health impacts for people in prison. Australian \& New Zealand Journal of Psychiatry, 0004867420937806

[80] Binswanger, I. A., Stern, M. F., Deyo, R. A., Heagerty, P. J., Cheadle, A., Elmore, JG., \&Koepsell, TD. (2007). Release from prison-A high risk of death for former inmates. New England Journal of Medicine, 356(2), 157-165.

[81] Binswanger, I. A., Blatchford, P. J., Lindsay, R. G., \& Stern, MF. (2011). Risk factors for all-cause, overdose and early deaths after release from prison in Washington state. Drug and Alcohol Dependence, 117(1), 1-6.

[82] Cochran, JC., \& Mears, DP. (2013). Social isolation and inmate behavior: A conceptual framework for theorizing prison visitation and guiding and assessing research. Journal of Criminal Justice, 41(4), 252-261.

[83] Wurcel, AG., Dauria, E., Zaller, N., Nijhawan, A., Beckwith, C., Nowotny, K., \& Brinkley-Rubinstein, L. (2020). Spotlight on jails: COVID-19 mitigation policies needed now. Clinical Infectious Diseases. 71(15):890-1.

[84] UN Subcommittee on the Prevention of Torture. (2020). Advice of the Subcommittee on Prevention of Torture to States Parties and National Preventive Mechanisms relating to the Coronavirus Pandemic. Available from https://www.ohchr.org/Documents/ HRBodies/OPCAT/AdviceStatePartiesCoronavirusPandemic2020.pdf

[85] Epperson, MW., \& Pettus-Davis, C. (2017). Smart Decarceration. Smart Decarceration: Achieving Criminal Justice Transformation in the 21st Century, Working Paper No.3.

[86] Bradley, A. B. (2018). Ending overcriminalization and mass incarceration: Hope from civil society. Cambridge University Press: Cambridge.

[87] Jacobson, M. (2005). Downsizing prisons: How to reduce crime and end mass incarceration. New York: NYU Press.

[88] Petersilia, J., \& Cullen, F. T. (2014). Liberal but not stupid: Meeting the promise of downsizing prisons. Stanford Journal of Criminal Law and Policy(Vol.2).

[89] Pettus-Davis, C., \& Epperson, M. W. (2015). From Mass Incarceration to SmartDecarceration: American Academy of Social Work \& Social Welfare. Available from http://aaswsw.org/wpcontent/uploads/2015/03/From-Mass-Incarceration-to-Decarceration3.24.15.pdf

[90] Data For Progress. (2020). Fighting Coronavirus with Decarceration: Policies and Polling. Available from: https:/filesforprogress.org/ memos/fighting-coronavirus-with-decarceration.pdf

[91] Sundt, J., Salisbury, E. J., \& Harmon, M. G. (2016). Is downsizing prisons dangerous? The effect of California's Realignment Act on public safety. Criminology \& Public Policy, 15(2), 315-341.

[92] Lofstrom, M., \& Raphael, S. (2013). Impact of realignment on county jail populations. Public Policy Institute of California. 
[93] Lofstrom, M., \& Raphael, S. (2015). Realignment, incarceration, and crime trends in California. Public Policy Institute of California.

[94] Kalinin, I.Y. (2002). The Russian penal system: past, present and future. Lecture Series. International Centre for Prison Studies, King's College London. Available from: https://prisonstudies.org/sites/ default/files/resources/downloads/website_kalinin.pdf

[95] Romans, S. (2020). Eerstecoronabesmettingvastgesteld in Belgischegevangenis. HLN. Retrieved from https://www.hln.be /nieuws/binnenland/eerste-coronabesmetting-vastgesteld-in-belgische -gevangenis $\sim \mathrm{a} 8 \mathrm{~b} 6 \mathrm{bcea} /$ ?referer=https $\% 3 \mathrm{~A} \% 2 \mathrm{~F} \% 2 \mathrm{Fwww}$.google com $\% 2 \mathrm{~F} \&$ referer $=\mathrm{https} \% 3 \mathrm{~A} \% 2 \mathrm{~F} \% 2 \mathrm{~F}$ theconversation.com $\% 2 \mathrm{~F}$

[96] Amnesty International. (2015). 'Mandela Rules' on Prisoner Treatment Adopted in Landmark Revision of UN Standards. Retrieved on 20 April 2020 from https://www.amnesty.org/en/pressreleases $/ 2015 / 05 / \mathrm{ma}$ ndela-rules-on-prisoner-treatment-adopted-inlandmark -revision-of-un-standards-1/ 